\title{
Relationship between Fruiting, Specific Leaf Weight, and Subsequent Spur Productivity in Walnut
}

\author{
I. Klein', S.A. Weinbaum ${ }^{2}$ T.M. DeJong, and T.T. Muraoka \\ Department of Pomology, University of California, Davis, CA 95616 \\ Additional index words. alternate bearing, canopy light relations, catkins, Juglans regia, distillate flowers
}

Abstract. Localized and carry-over effects of light exposure [as inferred from specific leaf weight (SLW)] on spur viability, flowering, and fruit set were monitored in selected spurs throughout walnut (Juglans regia, CVS. Serr and Hartley) tree canopies. Shaded spurs (i.e., average SLW $<4 \mathrm{mg} \cdot \mathrm{cm}^{-2}$ ) were predisposed to die during the winter, and spur mortality was accentuated among spurs that had borne fruit that season. More catkins and distillate flowers per spur were characteristic of the more exposed positions within the canopy (as indicated by SLW) during the previous summer and following an "off" year. In exposed 'Serr' canopy positions (SLW >5 mg.cm-2), catkin and pistillate flower maturation was reduced in fruiting spurs by $60 \%$ and $30 \%$, respectively, in the subsequent year relative to vegetative spurs. In 'Hartley', the number of distillate flowers was also reduced by $35 \%$ on spurs that fruited the previous year relative to spurs that had been vegetative. Maximum rates of return bloom and fruit set were evident in spurs exhibiting the highest SLW and $N$ per unit leaf area $\left(N_{A}\right)$, specific to each cultivar. Among spurs of both cultivars, distillate flower development was more sensitive to shading in the previous season than was catkin development. Shell weight of 'Serr' varied positively with SLW, but kernel weight, fruit N, and oil concentration did not vary "with SLW in either cultivar.

Vegetative growth (Barritt et al., 1987; Jackson and Palmer, 1977a; Robinson et al., 1983), flowering (Jackson and Palmer, 1977b), fruit set (Doud and Ferree, 1980; Jackson and Palmer, 1977b; Stephenson, 1981), and fruit quality (Doud and Ferree, 1980; Erez and Flore, 1986; Jackson et al., 1977; Patten and Proebsting, 1986; Robinson et al., 1983; Tustin et al., 1988) are affected by light exposure and the availability of photosynthates. Nitrogen allocated to leaves within tree canopies varies with light exposure (DeJong et al., 1989 and references cited therein). It has been shown that SLW and $\mathrm{N}_{\mathrm{A}}$ increase with available light within tree canopies (Barden, 1974, 1978; Barritt et al., 1987; DeJong, 1983; DeJong and Doyle, 1985; DeJong et al., 1989; Doud and Ferree, 1980; Jackson and Palmer, 1977a; Kappel and Flore, 1983; Klein et al., 1990; Marini and Marini, 1983; MacMillen and McClendon, 1983; Weinbaum et al., 1989).

Mature walnut orchards are among the most shaded of any deciduous fruit tree species grown in California, and SLW may vary with light exposure as much as 3 -fold within individual walnut tree canopies (Erez and Weinbaum, 1985). Our objective was to determine how flowering and fruiting vary within walnut tree canopies and are influenced by light exposure as inferred from SLW. We have reported recently (Klein et al., 1990) that SLW is highly indicative of natural light exposure in walnut tree canopies. Our intention was also to develop diagnostically useful SLW values to assess the adequacy of light exposure for reproductive development in walnut tree canopies. The presence/absence of developing fruit (i.e., "on" vs. "off" spurs) on subsequent spur viability, flowering, and fruit set in the following year has also been considered.

Received for publication 13 July 1990. This work was funded in part by the California Walnut Marketing Board. The cost of publishing this paper was defrayed in part by the payment of page charges. Under postal regulations, this paper therefore must be hereby marked advertisement solely to indicate this fact.

'On sabbatic leave from the Institute of Horticulture, ARO, The Volcani Center, Bet-Dagan, 50250 Israel.

'To whom all correspondence should be directed.

\section{Materials and Methods}

Plant material and sampling procedure. Five individual tree replicates of each of the Persian walnuts 'Serr' and 'Hartley', grafted on northern California black walnut seedling rootstock, were selected in a commercial orchard growing in Winters, Calif. Trees were 16 years old and planted $8.5 \times 8.5 \mathrm{~m}$ in a westeast orientation with closed canopies 8 to $10 \mathrm{~m}$ high. In Sept. 1988, 250 pairs (50 pairs per tree) of fruiting and nonfruiting spurs were tagged in each cultivar. Pairs of adjacent fruiting and nonfruiting spurs were selected so that each would be represented equally throughout the tree canopies. These paired spurs were tagged and numbered so that they could be identified during the 1989 growing season. Spurs selected and labeled in 1988 were categorized in Spring 1989 according to their survival and reproductive behavior. Spur classes (1989) were as follows: "a" = dead, "b" = vegetative, "c" = flowered but did not fruit, "d" = one of the tagged pair, either the vegetative or the fruiting spur (in 1988), flowered and fruited in 1989 and, "e" = the vegetative and reproductive spurs (1988) flowered and fruited in 1989. One to three middle leaflets from each tagged spur and 100 mature fruits per cultivar (20 per tree) from tagged fruiting spurs were sampled in Sept. 1988 for subsequent analysis.

Vegetative and reproductive development of tagged spurs was monitored in Spring 1989. Catkins per spur were counted subsequent to growth resumption. The number of growing buds (new spurs), distillate flowers, and fruits was counted and recorded at intervals of 5 to 7 days, from budbreak until fruit drop ceased.

Analytical procedures. Leaf area was measured with a Delta $\mathrm{T}$ area meter (Decagon, Pullman, Wash.) and then leaves were washed, dried at $55 \mathrm{C}$, and ground to pass a 30-mesh screen.

Nuts were air dried until they reached constant weight, and kernels and shells were weighed separately. Kernels were ground in a mortar and pestle for $\mathrm{N}$ and oil determinations. Digestion

Abbreviations: $\mathrm{N}_{\mathrm{A}}, \mathrm{N}$ per unit leaf area; $\mathrm{N}_{\mathrm{w}}$, leaf $\mathrm{N}$ concentration; SLW, specific leaf weight. 
Table 1. Association of SLW and leaf $\mathrm{N}$ in fruiting ("on") and nonfruiting ("off") 'Hartley' spurs in 1988 with their reproductive growth in 1989.

\begin{tabular}{|c|c|c|c|c|c|}
\hline \multirow{3}{*}{$\begin{array}{c}\text { Spur } \\
\text { class } \\
(1989)\end{array}$} & \multirow{3}{*}{$\begin{array}{c}\text { Spurs } \\
\text { in each } \\
\text { class }(\%)\end{array}$} & \multirow{2}{*}{\multicolumn{2}{|c|}{1988}} & \multicolumn{2}{|c|}{1989} \\
\hline & & & & \multirow[b]{2}{*}{$\begin{array}{l}\text { Catkins }^{\mathbf{z}} \\
\text { (no./spur) }\end{array}$} & \multirow{2}{*}{$\begin{array}{c}\text { Pistillate }^{z} \\
\text { flowers } \\
\text { (no./spur) }\end{array}$} \\
\hline & & $\begin{array}{c}\mathrm{SLW}^{\mathrm{z}} \\
\left(\mathrm{mg} \cdot \mathrm{cm}^{-2}\right)\end{array}$ & $\begin{array}{c}\mathrm{N}_{\mathrm{A}}^{z} \\
\left(\mu \mathrm{g} \cdot \mathrm{mm}^{-2}\right)\end{array}$ & & \\
\hline \multicolumn{6}{|c|}{ "Off"' spurs } \\
\hline$a^{y}$ & 11 & $4.09 \pm 0.13^{x}$ & $1.01 \pm 0.04$ & 0.00 & 0.00 \\
\hline $\mathrm{b}$ & 59 & $4.60 \pm 0.09$ & $1.21 \pm 0.02$ & $0.29 \pm 0.06$ & 0.00 \\
\hline $\mathrm{c}$ & 20 & $5.47 \pm 0.17$ & $1.42 \pm 0.04$ & $1.00 \pm 0.19$ & $1.69 \pm 0.11$ \\
\hline d & 7 & $5.98 \pm 0.40$ & $1.59 \pm 0.10$ & $1.13 \pm 0.40$ & $2.33 \pm 0.21$ \\
\hline $\mathrm{e}$ & 3 & $7.36 \pm 0.25$ & $1.82 \pm 0.08$ & $1.88 \pm 0.67$ & $3.00 \pm 0.42$ \\
\hline \multicolumn{6}{|c|}{ "On' spurs } \\
\hline a & 65 & $4.03 \pm 0.08$ & $0.66 \pm 0.02$ & 0.00 & 0.00 \\
\hline $\mathrm{b}$ & 26 & $4.75 \pm 0.13$ & $0.93 \pm 0.04$ & $0.16 \pm 0.08$ & 0.00 \\
\hline c & 4 & $7.51 \pm 0.34$ & $1.60 \pm 0.07$ & $1.67 \pm 0.55$ & $2.10 \pm 0.18$ \\
\hline d & 2 & $5.10 \pm 0.56$ & $0.99 \pm 0.20$ & -.- & $1.50 \pm 0.29$ \\
\hline e & 3 & $7.47 \pm 0.47$ & $1.61 \pm 0.11$ & $1.88 \pm 0.58$ & $1.88 \pm 0.23$ \\
\hline
\end{tabular}

${ }^{2}$ Leaf determinations were made in Sept. 1988; catkins and pistillate flowers were counted in Apr. 1989.

'Spur classes were: $\mathrm{a}=$ dead, $\mathrm{b}=$ vegetative, $\mathrm{c}=$ flowering but not fruiting, $\mathrm{d}=$ one of the tagged pair, either the vegetative or the reproductive spur, fruiting, and $\mathrm{e}=$ both, vegetative and reproductive spurs fruiting.

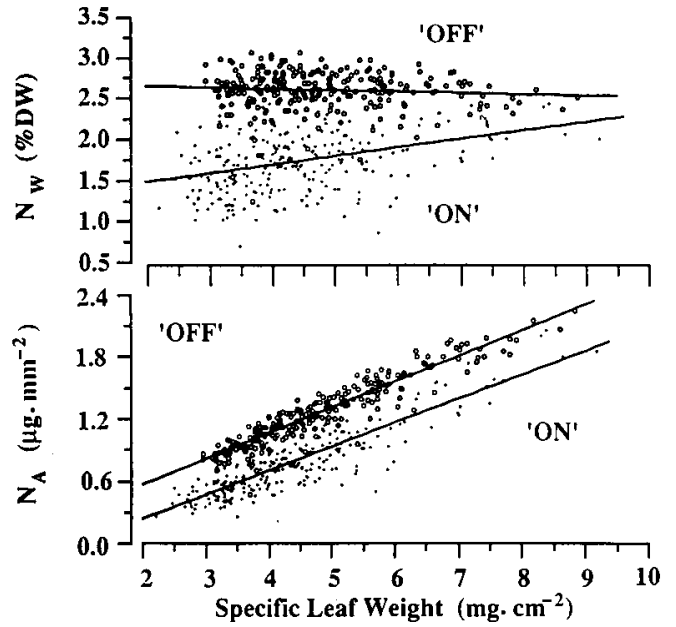

Fig. 1. The correlation between SLW $\left(\mathrm{mg} \cdot \mathrm{cm}^{-2}\right), \mathrm{N}_{\mathrm{A}}\left(\mu \mathrm{g} \cdot \mathrm{mm}^{-2}\right)$, and $\mathrm{N}_{\mathrm{w}}$ (percent dry weight) of 'Hartley' spur leaflets in Sept. 1988. "Off" and "on" refer to 250 nonfruiting and fruiting spurs, each, respectively. Correlation coefficients (r) were: 0.071 ( $\mathrm{N}_{\mathrm{w}} / \mathrm{SLW}$ "off"), $0.349\left(\mathrm{~N}_{\mathrm{w}} / \mathrm{SLW}\right.$ “on"), $0.936\left(\mathrm{~N}_{\mathrm{A}} / \mathrm{SLW}\right.$ “off”), and $0.888\left(\mathrm{~N}_{\AA} /\right.$ SLW “on”).

of leaf and fruit samples and conductimetric determination of $\mathrm{N}$ were performed according to Carlson (1978). Oil determinations were carried out by the method of Lewis et al. (1978). For oil extraction, $1.5 \mathrm{~g}$ of kernel tissue was homogenized for

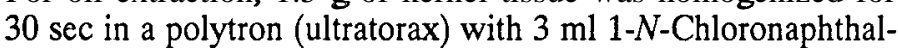
ene (I-N-Cl), at a medium speed and filtered through Whatman no. 4 filter paper. An oil standard curve (0 to $50 \%$ w/v) was constructed by mixing and homogenizing $100 \%$ pure-expeller pressed walnut oil, purchased at a local supermarket, and 1-NC1. Refractive index of samples and standards was measured with a thermostated Abbé refractometer at $25 \mathrm{C}$.

\section{Results and Discussion}

Relationship between SLW and $N_{A}$ on reproductive and vegetative spurs. SLW varied with light exposure in walnut tree

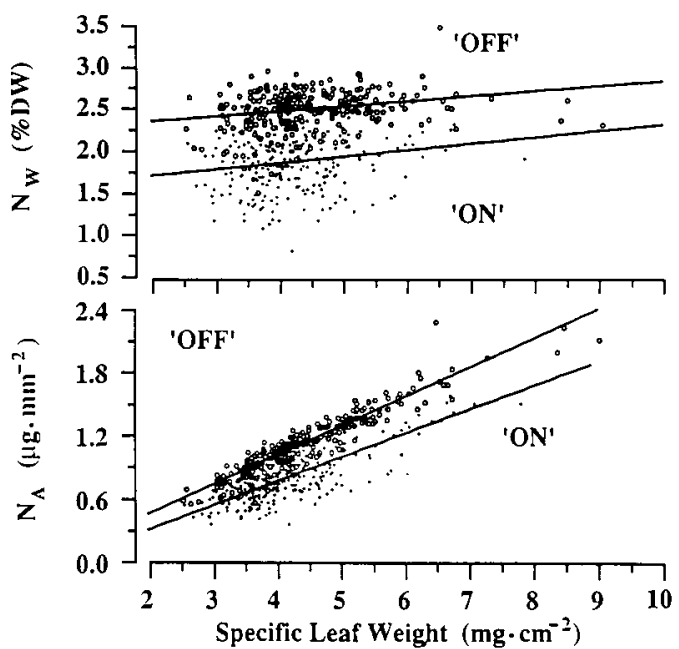

Fig. 2. The correlation between SLW $\left(\mathrm{mg} \cdot \mathrm{cm}^{-2}\right), \mathrm{N}_{\mathrm{A}}\left(\mu \mathrm{g} \cdot \mathrm{mm}^{-2}\right)$, and $\mathrm{N}_{\mathrm{w}}$ (percent dry weight) of 'Serr' spur leaflets in Sept. 1988. "Off" and "on" refer to 250 nonfruiting and fruiting spurs, each, respectively. Correlation coefficients (r) were: 0.192 ( $\mathrm{N}_{\mathrm{w}} / \mathrm{SLW}$ "off' '), 0.251 ( $\mathrm{N}_{\mathrm{w}} / \mathrm{SLW}$ “on”), $0.937\left(\mathrm{~N}_{\mathrm{A}} \mathrm{SLW}\right.$ “off”), and $0.813\left(\mathrm{~N}_{\mathrm{A}} /\right.$ SLW “on”).

canopies (Klein et al., 1990) and was correlated significantly with $\mathrm{N}_{\mathrm{A}}$ before harvest in Sept. 1988 (Figs. 1 and 2). Spurs carrying mature fruit (i.e., "on" spurs) had lower $\mathrm{N}_{\mathrm{A}}$ and leaf $\mathrm{N}$ concentration $\left(\mathrm{N}_{\mathrm{w}}\right)$ at comparable SLW than did nonbearing ("off") spurs. At the time of fruit maturation, correlation coefficients $(r)$ between SLW and $\mathrm{N}_{\mathrm{A}}$ of vegetative ("off") and reproductive ("on") spurs were 0.936 and 0.888 for 'Hartley' and 0.937 and 0.813 for 'Serr', respectively. $\mathrm{N}_{\mathrm{w}}$ of "on" spurs was weakly correlated with SLW (Figs. 1 and 2).

Relationship between SLW and cropping on subsequent spur viability and flowering. Carry-over effects of light exposure (as inferred from measurement of SLW, Klein et al., 1990) and cropping in 1988 on catkin abortion, spur viability, and return distillate bloom were evaluated in Spring 1989 (Tables 1 and 2). 
Table 2. Association of SLW and leaf $\mathrm{N}$ in fruiting (“on") and nonfruiting ("off") 'Serr' walnut spurs in 1988 with their reproductive growth in 1989.

\begin{tabular}{|c|c|c|c|c|c|}
\hline \multirow{3}{*}{$\begin{array}{c}\text { Spur } \\
\text { class } \\
(1989) \\
\end{array}$} & \multirow{3}{*}{$\begin{array}{c}\text { Spurs } \\
\text { in each } \\
\text { class } \\
(\%)\end{array}$} & \multirow{2}{*}{\multicolumn{2}{|c|}{1988}} & \multicolumn{2}{|c|}{1989} \\
\hline & & & & \multirow[b]{2}{*}{$\begin{array}{c}\text { Catkins }^{z} \\
\text { (no./spur) }\end{array}$} & \multirow{2}{*}{$\begin{array}{l}\text { Pistillate }^{z} \\
\text { flowers } \\
\text { (no./spur) }\end{array}$} \\
\hline & & $\begin{array}{c}\mathrm{SLW}^{\mathrm{z}} \\
\left(\mathrm{mg} \cdot \mathrm{cm}^{-2}\right)\end{array}$ & $\begin{array}{c}\mathrm{N}_{\mathrm{A}}{ }^{2} \\
\left(\mu \mathrm{g} \cdot \mathrm{mm}^{-2}\right)\end{array}$ & & \\
\hline \multicolumn{6}{|c|}{ "Off"' spurs } \\
\hline$a^{y}$ & 18 & $4.01 \pm 0.10^{x}$ & $0.98 \pm 0.03$ & 0.00 & 0.00 \\
\hline $\mathrm{b}$ & 63 & $4.48 \pm 0.07$ & $1.14 \pm 0.02$ & $2.20 \pm 0.13$ & 0.00 \\
\hline c & 6 & $4.92 \pm 0.24$ & $1.29 \pm 0.09$ & $1.50 \pm 0.47$ & $2.23 \pm 0.43$ \\
\hline d & 9 & $5.31 \pm 0.27$ & $1.35 \pm 0.07$ & $2.73 \pm 0.57$ & $3.41 \pm 0.43$ \\
\hline e & 4 & $5.66 \pm 0.25$ & $1.45 \pm 0.07$ & $3.00 \pm 1.07$ & $4.30 \pm 0.56$ \\
\hline \multicolumn{6}{|c|}{ "On" spurs } \\
\hline$a$ & 28 & $3.94 \pm 0.07$ & $0.71 \pm 0.03$ & 0.00 & 0.00 \\
\hline $\mathrm{b}$ & 52 & $4.17 \pm 0.07$ & $0.80 \pm 0.02$ & $0.34 \pm 0.08$ & 0.00 \\
\hline c & 3 & $4.27 \pm 0.25$ & $0.76 \pm 0.05$ & $0.43 \pm 0.43$ & $1.57 \pm 0.43$ \\
\hline d & 13 & $5.19 \pm 0.18$ & $1.07 \pm 0.04$ & $1.45 \pm 0.31$ & $2.16 \pm 0.28$ \\
\hline $\mathrm{e}$ & 4 & $5.40 \pm 0.24$ & $1.06 \pm 0.07$ & $0.91 \pm 0.25$ & $2.82 \pm 0.69$ \\
\hline
\end{tabular}

${ }^{\mathrm{z}}$ Leaf determinations were made in Sept. 1988; catkins and pistillate flowers were counted in Apr. 1989.

${ }^{y}$ Spur classes were: $\mathrm{a}=$ dead, $\mathrm{b}=$ vegetative, $\mathrm{c}=$ flowering but not fruiting, $\mathrm{d}=$ one of the tagged pair, either the vegetative or the reproductive spur, fruiting, and $\mathrm{e}=$ both, vegetative and reproductive spurs fruiting.

${ }^{x}$ Mean \pm SE.

Spur mortality (class "a") was evident in both walnut cultivars (Tables 1and 2). The rnajority of surviving spurs, in both cultivars, failed to flower in Spring 1989 (class "b"). In 'Hartley', more "off" than "on" spurs flowered (class "c"), while "off" and "on" spurs (1988) of 'Serr' had similar percentages of reproductive spurs (1989; classes "c", "d", and "e").

Spur survival and reproductive development in 1989 were clearly related to light exposure as inferred by SLW and $\mathrm{N}_{\mathrm{A}}$ content of the spur leaf in the previous year. Spurs that died over Winter 1988-89 had the lowest average SLW $\left(\approx 4 \mathrm{mg} \cdot \mathrm{cm}^{-2}\right)$ and $\mathrm{N}_{\mathrm{A}}$ in 1988 (Tables 1 and 2). Spur death may have resulted from limited photosynthesis and resource availability. Excessively shaded spurs may also have limited sink strength.

SLW of class "e" 'Hartley' spurs (in which both members of the pair fruited) reached $\approx 7.5 \mathrm{mg} \cdot \mathrm{cm}^{-2}$ and that of 'Serr' $\approx 5.5 \mathrm{mg} \cdot \mathrm{c} \mathrm{m}^{-2}$ in "off" and "on" spurs (Tables 1 and 2). There was a tendency for flowering and fruit set to be associated positively with higher $\mathrm{N}_{\mathrm{A}}$ content, particularly in the case of "off" spurs (Tables 1 and 2). $\mathrm{N}_{\mathrm{A}}$ values of 'Serr' were lower than those of 'Hartley' at fruit maturity (compare Tables 1 and 2). Given the well-established correlation between $\mathrm{N}_{\mathrm{A}}$ and leaf photosynthetic capacity (DeJong and Doyle, 1985), photosynthesis, particularly in 'Serr', was probably limited by $\mathrm{N}$ availability in "on" spurs, which consequently reduced the development of reproductive organs. Walnut kernels that contain high $\mathrm{N}$ concentrations may have mobilized $\mathrm{N}$ from spur leaves and accelerated leaf senescence on fruiting ("on") spurs. NW varied little with canopy position in 1988 and was independent of flowering and fruit set in 1989 (data not presented).

Spur viability and the number of catkins and distillate flowers per spur increased with SLW and $\mathrm{N}_{\mathrm{A}}$. Catkins are evident microscopically at the time of canopy closure in early summer, and may abort soon after initiation, particularly in shaded regions of the canopy (Ryugo et al., 1980). Catkin retention varied positively with SLW and $\mathrm{N}_{\mathrm{A}}$ in both "off" and "on" spurs of 'Hartley' (Table 1). 'Hartley' spurs carried fewer catkins than did 'Serr' spurs (Tables 1 and 2). In 'Serr', catkin retention was considerably greater on nonfruiting ("off") spurs than on fruit- ing spurs and increased in "on" spurs only as SLW and $\mathrm{N}_{A}$ increased (Table 2). Distillate flower development was more sensitive to shading than was catkin retention (Tables 1 and 2). Thus, some catkins but not distillate flowers matured on class "b" spurs.

Following an "off" year, the number of distillate flowers per 'Hartley' spur varied positively with SLW and $\mathrm{N}_{\mathrm{A}}$ (Table 1). There were more distillate flowers per spur following the "off" than the "on" year (Table 1). In 1988, "on" class "c" spurs had leaves with similar SLW, $\mathrm{N}_{\mathrm{A}}$, and reproductive organs as class "e" (Table 1). Fruit set may have been pollen-limited, particularly on the more exposed spurs, because it rained for 2 days during the period of distillate flower receptivity in 'Hartley'. The number of distillate flowers per spur in 'Serr' almost doubled as SLW and $\mathrm{N}_{\mathrm{A}}$ increased following the spur "off" and "on" cycling phases, respectively (Table 2).

Effect of cultivar and cropping on spur development in the subsequent years. The presence of fruit in 1988 had a much greater impact on subsequent spur development in 'Hartley' than in 'Serr'. This difference is indicated by the fact that "off"/ "on" ratios differed from unity in 'Hartley' to a much greater extent than in 'Serr' (Table 3).

The regularity of fruiting was greater in well-exposed canopy positions (i.e., SLW $>5.0 \mathrm{mg} \cdot \mathrm{cm}^{-2}$ ) relative to those more

Table 3. Effect of previous year (1988) cropping (“on" vs. "off”) on the percentage of spur mortality, flowering, and fruiting in 1989 in 'Hartlev' (H) and 'Serr' $(\mathrm{S})$ walnut trees.

\begin{tabular}{|c|c|c|c|c|c|c|c|}
\hline \multirow{3}{*}{$\begin{array}{l}\text { Spur } \\
\text { classes }\end{array}$} & \multirow{3}{*}{$\begin{array}{r}\text { Spur fate } \\
(1989)\end{array}$} & \multicolumn{2}{|c|}{$\begin{array}{c}\text { "Off" } \\
1988\end{array}$} & \multicolumn{2}{|c|}{ “'On” 1988} & \multirow{2}{*}{\multicolumn{2}{|c|}{ Off : on ratios }} \\
\hline & & \multirow{2}{*}{$\begin{array}{c}\mathrm{H} \\
(\%)\end{array}$} & \multirow{2}{*}{$\underset{(\%)}{S}$} & \multirow{2}{*}{$\begin{array}{c}\mathrm{H} \\
(\%)\end{array}$} & \multirow{2}{*}{$\underset{(\%)}{S}$} & & \\
\hline & & & & & & $\mathrm{H}$ & $S$ \\
\hline a & Died & 11 & 18 & 65 & 28 & 0.17 & 0.64 \\
\hline b & Vegetative & 59 & 63 & 26 & 52 & 2.27 & 1.21 \\
\hline $\mathrm{c}, \mathrm{d}, \mathrm{e}$ & Flowered ${ }^{z}$ & 30 & 19 & 9 & 20 & 3.33 & 0.95 \\
\hline$d, e$ & Set fruit & 10 & 13 & 5 & 17 & 2.00 & 0.76 \\
\hline
\end{tabular}

zPistillate bloom. 
shaded (i.e., exhibiting lower SLW). Maximum rates of return bloom and fruit set were achieved on spurs exhibiting the highest SLW and $\mathrm{N}_{\mathrm{A}}$ content of spur leaves, specific to each cultivar. In 'Serr', catkin and distillate flower count was reduced by $60 \%$ and $35 \%$, respectively, following "on" compared with "off" spur cycling (see highly exposed positions, spur classes "d" and "e", Table 2). In 'Hartley', catkin number per surviving spur was not affected, but distillate flower count per spur was reduced by $35 \%$ following "on" vs. "off" years (Table 1). Alternate bearing is ubiquitous among deciduous and evergreen tree species (Monselise and Goldschmidt, 1983). We are unaware, however, of any discussion in the literature concerning the role of light exposure on branch or spur alternation.

Relationship between SL W, nut size and kernel composition. The percentage $\mathrm{N}$ in 'Hartley' kernels was slightly less than that in 'Serr' (Table 4). The two cultivars had similar oil concentrations. No correlations were found between SLW and nut attributes, with the exception of a positive correlation $(r=0.615)$ with shell weight in 'Serr'. Percent kernel was, therefore, correlated negatively $(r=0.584)$ with SLW in 'Serr', although actual kernel weight was not influenced.

Our data indicate considerable autonomy among walnut spurs. That is, the fate and reproductive potentiality of individual spurs varied with light exposure (as measured by leaf attributes) and previous crop load. This result is not surprising since leaves preferentially supply assimilates to associated spurs (Stephenson, 1981). The ability of developing buds on the spur to use assimilates may also be influenced by the intensity and quality of light impinging directly on those buds. Watson and Casper (1984) championed the view that higher plants are assemblages of semi-autonomous, integrated physiological units or modules (such as spurs) with respect to the assimilation, distribution, and use of carbon, including vegetative vs. reproductive development. Some morphological units will be capable of gaining sufficient resources to support fruit growth and the development of additional reproductively competent modules, while others, which command fewer resources, remain vegetative or cease to function altogether. That is, the developmental directions affecting the fates of meristems are determined locally.

The effects of severe shading on some aspects of 'Hartley' walnut spur and fruit development have been reported (Ryugo et al., 1980, 1985). We have extended the scope of those studies by measuring light exposure throughout mature walnut tree canopies and its relationship to SLW (Klein et al., 1990). In the present study we have explored the relationship between light exposure (as inferred from SLW) and cropping.

The plasticity of leaves is such that attributes such as SLW and $\mathrm{N}_{\mathrm{A}}$ vary continuously with the light gradient throughout tree canopies. The strong correlation between leaf attributes, particularly SLW, and photosynthetic photon flux throughout tree canopies permits us to exploit leaves as biological integrators of the light microenvironment. A quantitative calibration

Table 4. Nut attributes in 'Hartley' and 'Serr' in 1988.

\begin{tabular}{lrr}
\hline \hline Attribute & \multicolumn{1}{c}{ 'Hartley' } & \multicolumn{1}{c}{ 'Serr' } \\
\hline Kernel N (percent dry wt) & $3.64 \pm 0.03$ & $3.96 \pm 0.05$ \\
Kernel oil (percent dry wt) & $60.73 \pm 0.45$ & $61.93 \pm 0.66$ \\
Kernel wt (g) & $4.84 \pm 0.09^{z}$ & $7.30 \pm 0.09$ \\
Shell wt (g) & $10.95 \pm 0.14$ & $4.93 \pm 0.06$ \\
Kernel (\%) & $43.95 \pm 0.33$ & $59.62 \pm 0.38$ \\
\hline
\end{tabular}

${ }^{\mathrm{z}}$ Mean $\pm \mathrm{SE}$ of production criteria (i.e., flowering, fruit set) in terms of readily measurable variables (i.e., SLW and $\mathrm{N}_{\mathrm{A}}$, which are reported here, may be used after proper implementation to improve orchard management practices.

\section{Literature Cited}

Barden, J.A. 1974. Net photosynthesis, dark respiration, specific leaf weight, and growth of young apple trees as influenced by light regime. J. Amer. Soc. Hort. Sci. 99:547-551.

Barden, J.A. 1978. Apple leaves, their morphology and photosynthetic potential. HortScience 13:644-646.

Barritt, B. H., C.R. Rem, K.R. Guelich, S.R. Drake, and M.A. Dilley. 1987. Canopy position and light effects on spur, leaf, and fruit characteristics of 'Delicious' apple. HortSclence 22:402-405.

Carlson, R.M. 1978. Automated separation and conductimetric determination of ammonia and dissolved carbon dioxide. Anal. Chem. 50:1528-1531.

DeJong, T.M. 1983. C0 assimilation characteristic of five Prunus tree fruit species. J. Amer. Soc. Hort. Sci. 108:303-307.

DeJong, T.M. and J.F. Doyle. 1985. Seasonal relationship between leaf nitrogen content (photosynthetic capacity) and leaf canopy light exposure in peach(Prunus persicu). Plant Cell \& Env. 8:701-706.

DeJong, T. M., K.R. Day, and R.S. Johnson. 1989. Partitioning of leaf nitrogen with respect to within canopy light exposure and nitrogen availability in peach (Prunus persica). Trees 3:89-95.

Doud, D.S. and D.C. Ferree. 1980. Influence of altered light levels on growth and fruiting of mature 'Delicious' apple trees. J. Amer. Soc. Hort. Sci. 105:325-328.

Erez, A. and J.A. Flore. 1986. The quantitative effect of solar radiation on 'Redhaven' peach fruit skin color. HortScience 21:1424-1426.

Erez, A. and S.A. Weinbaum. 1985. Field estimation of leaf nitrogen by light transmittance. J Plant Nutr. 8: 103-1 15.

Jackson, J.E. and J.W. Palmer. 1977a. Effects of shade on the growth and cropping of apple trees. I. Experimental details and effects on vegetative growth. J. Hort. Sci. 52:245-252.

Jackson, J.E. and J.W. Palmer. 1977b. Effects of shade on the growth and cropping of apple trees. 11. Effects on components of yield. J. Hort. Sci. 52:253-266.

Jackson, J. E., J.W. Palmer, M.A. Perring, and R.O. Sbarples. 1977. Effects of shade on the growth and cropping of apple trees. III. Effects of fruit growth, chemical composition and quality at harvest and after storage. J. Hort. Sci. 52:267282.

Kappel, F. and J.A. Flore. 1983. Effect of shade on photosynthesis, specific leaf weight, leaf chlorophyll content, and morphology of young peach trees. J. Amer. Soc. Hort. Sci. 108:541-544.

Klein, I., T.M. DeJong, S.A. Weinbaum, and T.T. Muraoka. 1991. Specific leaf weight and nitrogen allocation responses to natural light exposure within walnut tree canopies. HortScience 26:183-185.

Lewis, C. E., R. Morris, and K. O'Brien. 1978. The oil content of avocado mesocarp. J. Sci. Food. Agr. 29:943-949.

Marini, R.P. and M.C. Marini. 1983. Seasonal changes in specific leaf weight, net photosynthesis and chlorophyll content of peach leaves as affected by light penetration and canopy position. J. Amer. Soc. Hort. Sci. 108:600-605.

MacMillen, G.G. and J.H McClendon. 1983. Dependence of photosynthetic rates on leaf density thickness in deciduous woody plants grown in sun and shade. Plant Physiol. 72:674-678.

Monselise, S.P. and E.E. Goldschmidt. 1982. Alternate bearing in fruit trees. Hort. Rev. 4:128-173.

Patten, K.D. and E.L. Proebsting. 1986. Effect of different artificial shading times and natural light intensities on the fruit quality of 'Bing' sweet cherry. J. Amer. Soc. Hort. Sci. 111:360-363.

Robinson, T. L., E.J. Seely, and B.H. Barritt. 1983. Effect of light environment and spur age on 'Delicious' apple fruit size and quality. J. Amer. Soc. Hort. Sci. 108:855-861.

Ryugo, K., B. Marangoni, and D.E. Ramos. 1980. Light intensity and fruiting effects on carbohydrate contents, spur development, and return bloom of 'Hartley'. J. Amer. Soc. Hort. Sci. 105:223-227.

Ryugo, K., G. Bartolini, R.M. Carlson, and D.E. Ramos. 1985. Relationship between catkin development and cropping in the persian walnut 'Serr'. HortScience 20:1094-1096.

Stephenson, A.G. 1981. Flower and fruit abortion; proximate causes and ultimate functions. Annu. Rev. Ecol. Syst. 12253-279.

Tustin, D. S., P.M. Hirst, and I.J. Barrington. 1988. Influence of orientation and position of fruiting laterals on canopy light penetration, yield, and fruit quality of 'Granny Smith' apple. J. Amer. Soc. Hort. Sci. 113:693-699.

Watson, M.A. and B.B. Casper. 1984. Morphogenetic constraints on patterns of carbon distribution in plants. Annu. Rev. Ecol Syst. 15:233-258.

Weinbaum, S.A., S.M. Southwick, K.A. Shackel, T.T. Muraoka, W. Krueger, and J.T. Yeager. 1989. Photosynthetic photon flux influences macroelement weight and leaf dry weight per unit leaf area in prone tree canopy. J. Amer. Soc. Hort. Sci. 114:720-723. 